\title{
Nuclear Fuel Cycle: Environmental Impact
}

\author{
Rodney C. Ewing (University of Michigan, USA)
}

\section{Nuclear Fuel Cycles}

Every energy source has environmental impacts-positive and negative. Nuclear power is a carbon-free source of energy that can reduce $\mathrm{CO}_{2}$ emissions by displacing the use of fossil fuels. The present level of carbon displacement is approximately 0.5 gigatonnes of carbon per year ( $\mathrm{GtC} /$ year), compared to the nearly $8 \mathrm{GtC} /$ year emitted by the use of fossil fuels. However, there are three major negative environmental impacts of nuclear power: catastrophic accidents, nuclear weapons, and nuclear waste. ${ }^{1}$ The last two, weapons and waste, are directly tied to the type of nuclear fuel cycle (Figure 4 in the main nuclear article by Raj et al. in this issue). The different fuel cycles reflect different strategies for the utilization of fissile nuclides, mainly ${ }^{235} \mathrm{U}$ and ${ }^{239} \mathrm{Pu}$, and these different strategies have important implications for nuclear waste management and nuclear weapons proliferation.

The "once-through" open cycle treats the spent fuel as a "waste" without any attempt to reclaim the remaining fissile nuclides, ${ }^{235} \mathrm{U}$ and newly created ${ }^{239} \mathrm{Pu}$, and the spent nuclear fuel (SNF) is directly disposed in a geological repository. This is the present strategy in the United States, and its success rests on the opening of the proposed geologic repository at Yucca Mountain in Nevada. A closed fuel cycle utilizes chemical reprocessing of the used fuel and retrieves approximately $99 \%$ of the fissile nuclides. However, the recovered fissile nuclides are only a supplement to the nuclear fuel that is mainly derived from newly mined uranium ore. The highly radioactive waste from reprocessing and the unprocessed SNF are disposed in a geological repository. Other fuel cycles are possible, such as the breeder reactor cycle, which creates more fissile material in the SNF than in the original fuel. The breeder reactor cycle envisions multiple cycles of reprocessing in order to extend the uranium resource. One can also develop fuel cycles based on ${ }^{232} \mathrm{Th}$ from which fissile ${ }^{233} \mathrm{U}$ is bred, as has been done in India. In 1977, President Carter decided to indefinitely defer reprocessing of spent nuclear fuel in the United States in order to have a more proliferation-resistant fuel cycle. In 1981, President Reagan lifted the ban on reprocessing, but he placed the financial responsibility for reprocessing on the private sector. By the mid-1980s, the commercial reprocessing of SNF had little attraction from a technical, economic, regulatory, or policy perspective. ${ }^{2}$ Thus, most of the spent fuel created at nuclear power plants has remained temporarily stored on site until a geologic repository is available.

To the extent that the choice between fuel cycles is driven by economic considerations, an open fuel cycle prevails as long as the price of uranium is lower than the cost of reprocessing. ${ }^{3}$ Thus, there are no simple criteria that can serve as a basis for the selection of a fuel cycle, as environmental, proliferation, and economic issues are closely tied to a nation's energy policy and that depends on the energy resources that are available to each country. Regardless of the type of nuclear fuel cycle that is envisioned, there will always be radioactive wastes that will require long-term solutions.
Recently, the Bush administration has proposed a series of initiatives, the Advanced Fuel Cycle Initiative and the Global Nuclear Energy Partnership, that envision a much increased use of nuclear power based on extensive chemical processing of used nuclear fuels to separate valuable and troublesome radionuclides. Separated transuranium elements, such as $\mathrm{Pu}, \mathrm{Np}$, $\mathrm{Cm}$, and Am, would be consumed in "burner" reactors that use fast neutrons. The neutron energy spectrum has a significant effect on the fission product yield, and the consumption of longlived actinides by fission is best achieved by fast neutrons. Short-lived fission product elements, such as ${ }^{137} \mathrm{Cs}$ and ${ }^{90} \mathrm{Sr}$, could be separated from long-lived fission product elements, such as ${ }^{99} \mathrm{Tc}$ and ${ }^{129} \mathrm{I}$, and different waste forms and disposal strategies would be used for each waste stream. The possibility of chemically processing the used fuel has stimulated renewed interest in the development of nuclear materials, including nuclear fuels for fast reactors and advanced nuclear waste forms for the special waste streams that will result. ${ }^{4,5}$ The design and selection of materials for the immobilization of nuclear waste has been the subject of more than 30 symposia on the Scientific Basis for Nuclear Waste Management held at the Materials Research Society meetings over the years. For present fuel cycles, the two principal waste forms are spent nuclear fuel (mainly $\mathrm{UO}_{2}$ ) for direct disposal and borosilicate glass for highlevel waste that remains after chemical reprocessing. Investigations of the corrosion and long-term durability of spent fuel and borosilicate glass in a wide range of repository conditions remains an active area of research.

During the past decade, one of the new opportunities has been the design and selection of highly durable ceramics for the immobilization of plutonium from dismantled nuclear weapons, as well as the "minor" actinides, such as $\mathrm{Np}, \mathrm{Cm}$, and Am. A number of complex oxides, silicates, and phosphates have been extensively investigated as potential hosts for actinides. ${ }^{6}$ The most studied phase is pyrochlore $\left(\mathrm{A}_{2} \mathrm{~B}_{2} \mathrm{O}_{7}\right)$ because of its ability to incorporate actinides; its chemical durability; and, for some compositions, its resistance to radiation damage. ${ }^{7}$ Systematic studies of radiation damage response have shown that compositions can be adjusted so that the dose at which the material becomes amorphous due to alpha-decay damage can be substantially reduced (Figure 1). These types of studies are a first step in the design of waste forms for specific waste stream compositions and for specific repository conditions. As an example, one could select the waste loading of a material based on the interplay between radiation damage accumulation and the anticipated thermal future of the repository. The development of highly durable materials for the "back end" of the nuclear fuel cycle will certainly improve the safety of the nuclear fuel cycle.

\section{Amount of Radioactive Waste}

The past 50 years of production of weapons materials and electric power have left the world with a considerable legacy of nuclear waste. Most of this nuclear waste is located in the United States and republics of the former Soviet Union (FSU). 


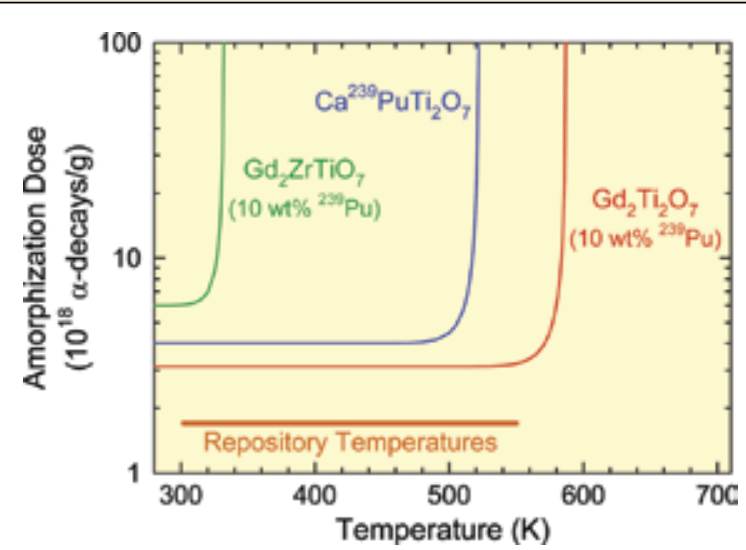

Figure 1. Predicted temperature dependence of amorphization in pyrochlore-related phases containing ${ }^{239} \mathrm{Pu} .{ }^{7}$ The curves bend upward at elevated temperatures due to thermal annealing. As the curves move to the left, the temperature at which complete annealing occurs decreases, and the waste form remains crystalline despite a high alpha-decay dose. The range of potential repository temperatures is indicated by the horizontal line.

Table I provides a summary of the nuclear waste inventories projected to the year 2010 for the United States (which has approximately one-quarter of the world's nuclear reactors). The inventories of waste in the FSU are certainly of the same order, but their form and distribution might vary considerably. ${ }^{8}$

\section{Table I: Summary of Estimated Nuclear Waste Inventories in the United States in 2010.}

\begin{tabular}{|c|c|}
\hline Spent nuclear fuel (commercial) & $\begin{array}{l}61,800 \mathrm{tHM} \\
39,800 \mathrm{MCi}\end{array}$ \\
\hline $\begin{array}{l}\text { Spent nuclear fuel (weapons } \\
\text { programs) }\end{array}$ & $2,500 \mathrm{tHM}$ \\
\hline High-level waste (reprocessing) & $\begin{array}{l}380,000 \mathrm{~m}^{3} \\
2,400 \mathrm{MCi}\end{array}$ \\
\hline Buried waste (LLW) & $\begin{array}{l}6.2 \text { million } \mathrm{m}^{3} \\
50 \mathrm{MCi}\end{array}$ \\
\hline \multicolumn{2}{|l|}{ Excess nuclear materials: } \\
\hline Highly enriched uranium & $174 t$ \\
\hline \multicolumn{2}{|l|}{ Plutonium } \\
\hline weapons capable & $38.2 \mathrm{t}$ \\
\hline $\begin{array}{l}\text { not weapons usable without } \\
\text { processing }\end{array}$ & $14.3 \mathrm{t}$ \\
\hline depleted uranium as $\mathrm{UF}_{6}$ & $700,000 t$ \\
\hline $\begin{array}{l}{ }^{137} \mathrm{Cs} \text { and }{ }^{90} \mathrm{Sr} \text { separated from HLW } \\
\text { in capsules as CsCl and } \mathrm{SrF}_{2}\end{array}$ & $90 \mathrm{GCi}$ \\
\hline Uranium mine and mill tailing & $\begin{array}{l}438 \text { million } \mathrm{m}^{3} \\
3,000 \mathrm{MCi}\end{array}$ \\
\hline Contaminated soil & $30-80$ million $\mathrm{m}^{3}$ \\
\hline Contaminated water & $1,800-4,700$ million $\mathrm{m}^{3}$ \\
\hline
\end{tabular}

Source: Reference 13.

Note: $\mathrm{t}=$ metric tonnes; $\mathrm{tHM}=$ metric tonnes of heavy metal.
The first step in the nuclear fuel cycle, mining and milling of uranium ore, has created huge volumes of material contaminated with low levels of radioactivity. ${ }^{9,10}$ In addition to the physical and chemical enrichment of uranium, which separates the uranium from its radioactive decay products, most nuclear reactors require enrichment of ${ }^{235} \mathrm{U}$ from the natural concentration of $0.7 \%$ to $4-5 \%$. One metric tonne of $\mathrm{UO}_{2}$ nuclear fuel has a total radioactivity of 0.1 terabequerels $(\mathrm{TBq})(1$ becquerel $=$ 1 disintegration $/ \mathrm{s} ; 1$ curie $\left.\left.(\mathrm{Ci})=3.7 \times 10^{10} \mathrm{~Bq}\right]\right)$, but the production of this $1 \mathrm{t}$ of fuel leaves residual activities of $1.2 \mathrm{TBq}$ as mine and mill tailing and $0.1 \mathrm{TBq}$ in depleted uranium from the enrichment process. ${ }^{11}$ The main radionuclides of concern in the tailings include ${ }^{238} \mathrm{U},{ }^{226} \mathrm{Ra},{ }^{222} \mathrm{Rn}$, and ${ }^{230} \mathrm{Th}$. Although the halflife of radon is short (3.8 days), radon is still a long-term concern because it is a decay product of ${ }^{226} \mathrm{Ra}$, which has a long half-life (1600 years). Unfortunately, other toxic elements, such as arsenic, are also often constituents of the mine and mill tailings. ${ }^{9,10}$

When nuclear fuel is removed from a reactor, the level of radioactivity has increased a million-fold $\left(10^{5} \mathrm{TBq}\right.$ per metric tonne of fuel) as a result of the creation of many hundreds of new radionuclides by a variety of in-reactor nuclear reactions, as is described in the following.

Fission of ${ }^{235} \mathrm{U}$ and ${ }^{239} \mathrm{Pu}$ creates a bimodal distribution of fission product elements. Some are short-lived, such as ${ }^{137} \mathrm{Cs}$ and ${ }^{90} \mathrm{Sr}$, with half-lives of approximately 30 years, but others, such as ${ }^{99} \mathrm{Tc}\left(213,000\right.$ years) and ${ }^{129} \mathrm{I}$ (16 million years) are long-lived.

Neutron capture followed by different decay schemes leads to the formation of transuranium nuclides (atomic number $>92$ ), mainly ${ }^{239} \mathrm{Pu}$, but also the minor actinides of $\mathrm{Np}, \mathrm{Cm}$, and Am. At present, global production of ${ }^{239} \mathrm{Pu}$ in the world's reactors is $70-90 \mathrm{t} /$ year, and the global inventory of this humanmade element is now just over $1800 \mathrm{t}$.

Activation products are formed, mainly in the structural components of the fuel assembly, such as ${ }^{60} \mathrm{Co},{ }^{14} \mathrm{C}$, and ${ }^{36} \mathrm{Cl}$. Despite the dramatic increase in radioactivity, the spent nuclear fuel is still mainly $\mathrm{UO}_{2}$. For a typical burnup of 40 megawatt days per kilogram of uranium $(\mathrm{MWd} / \mathrm{kgU})$, only $4 \%$ of the uranium has been consumed, converted to $1 \%$ transuranium elements and $3 \%$ fission products. The initial levels of radioactivity and heat decrease rapidly because they are mainly due to the presence of the short-lived fission product elements, whereas the level of radioactivity after a thousand years is due mainly to the actinides (uranium, ${ }^{239} \mathrm{Pu}$, and ${ }^{237} \mathrm{~Np}$ ) (Figure 2). More than 100,000 years of decay is required before the spent nuclear fuel finally returns to a level of activity comparable to that of the originally mined uranium with its decay-products. In the United States, reprocessing was done as part of the weapons programs (fuel from Pu-production reactors), and this has generated hundreds of thousands of cubic meters of high-level waste in the form of liquids and sludges that are stored mainly in tanks at Hanford, WA, and Savannah River, SC. The high-level waste is being vitrified as large "glass logs" in metal containers destined for disposal in a geologic repository. In other countries, such as France and Japan, the used nuclear fuel is chemically reprocessed to reclaim fissile nuclides, and the remaining wastes are vitrified and destined for geologic disposal.

\section{Geologic Disposal}

For many years, there has been a worldwide consensus that a geologic repository is the appropriate and safe solution to the disposal of spent nuclear fuel and/or the high-level waste generated by reprocessing. In the United States, the steps, schedule, 


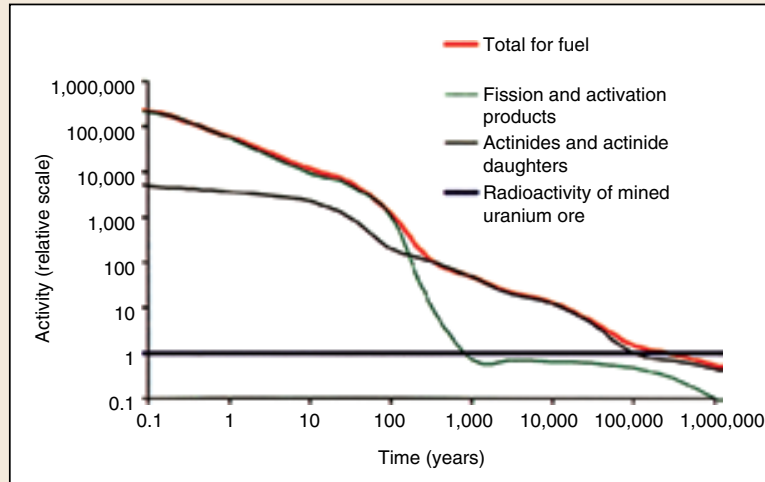

Figure 2. Relative radioactivity of spent nuclear fuel with a burnup of $38 \mathrm{MWd} / \mathrm{kgU}$. The activity is dominated by fission products during the first 100 years, thereafter by actinides. ${ }^{11}$

and requirements for the development of a geologic repository were outlined by the Nuclear Waste Policy Act of 1982. Worldwide, there are active programs of research and site investigations in a wide variety of rock types - clay in Belgium, salt in Germany, granite in Sweden and Finland, and volcanic tuff in Russia and the United States. However, to date, there is no geologic repository in operation that is receiving spent nuclear fuel or high-level nuclear waste. The challenge has not only been one of "politics," the development of regulations, and social acceptance, but also one of developing a strong scientific basis for the prediction of materials properties and repository performance over hundreds of thousands of years. ${ }^{12,13}$

\section{References}

1. R.L. Garwin, Interdiscip. Sci. Rev. 26, 265 (2001).

2. L.J. Carter, Nuclear Imperatives and Public Trust (Resources for the Future, Inc., Washington, DC, 1987).

3. E.N. von Hippel, Science 293, 2397 (2001)

4. W. Lutze, R.C. Ewing, Radioactive Waste Forms for the Future (NorthHolland, Amsterdam, 1988)

5. R.C. Ewing, Ed., Elements 2, 331 (2006)

6. R.C. Ewing, Prog. Nucl. Energy, 49, 635 (2007).

7. R.C. Ewing, W.J. Weber, J. Lian, J. Appl. Phys. 95, 5949 (2004).

8. National Research Council, End Points for Spent Nuclear Fuel and HighLevel Radioactive Waste in Russia and the United States (The National Academies Press, Washington, DC, 2003).

9. A. Abdelouas, Elements 2, 335 (2006).

10. K. Hart, in Energy, Waste and the Environment: A Geochemical Perspective, R. Gieré, P. Stille, Eds. (Geological Society, London, 2004), p. 25.

11. A. Hedin (SKB Technical Report 97-13, Swedish Nuclear Fuel and Waste Management Co., Stockholm, 1997).

12. A.M. Macfarlane, R.C. Ewing, Eds., Uncertainty Underground-Yucca Mountain and the Nation's High-Level Nuclear Waste (The MIT Press, Cambridge, MA, 2006).

13. R.C. Ewing, in Energy, Waste and the Environment: A Geochemical Perspective, R. Gieré, P. Stille, Eds. (Geological Society, London, 2004), p. 7.

\title{
Preventing Nuclear Weapon Proliferation as Nuclear Power Expands
}

\author{
Siegfried S. Hecker (Stanford University, USA)
}

Raj et al. ${ }^{1}$ describe the promise of nuclear energy as a sustainable, affordable, and carbon-free source available this century on a scale that can help meet the world's growing need for energy and help slow the pace of global climate change. However, the factor of millions gain in energy release from nuclear fission compared to all conventional energy sources that tap the energy of electrons (Figure 1) has also been used to create explosives of unprecedented lethality and, hence, poses a serious challenge to the expansion of nuclear energy worldwide. Although the end of the cold war has eliminated the threat of annihilating humanity, the likelihood of a devastating nuclear attack has increased as more nations, subnational groups, and terrorists seek to acquire nuclear weapons.

The development of commercial nuclear power has had to cope with the specter of potentially aiding the spread of nuclear weapons for its 50 years of existence. Although commercial nuclear power plants have not directly led to weapons proliferation, the technology and infrastructure for commercial and research reactor fuel cycles permit countries to come perilously close to obtaining the fissile materials, ${ }^{235} \mathrm{U}$ or ${ }^{239} \mathrm{Pu}$, that fuel nuclear weapons. The challenge for expanding nuclear power worldwide is to limit the incremental proliferation risk that such expansion presents. The two

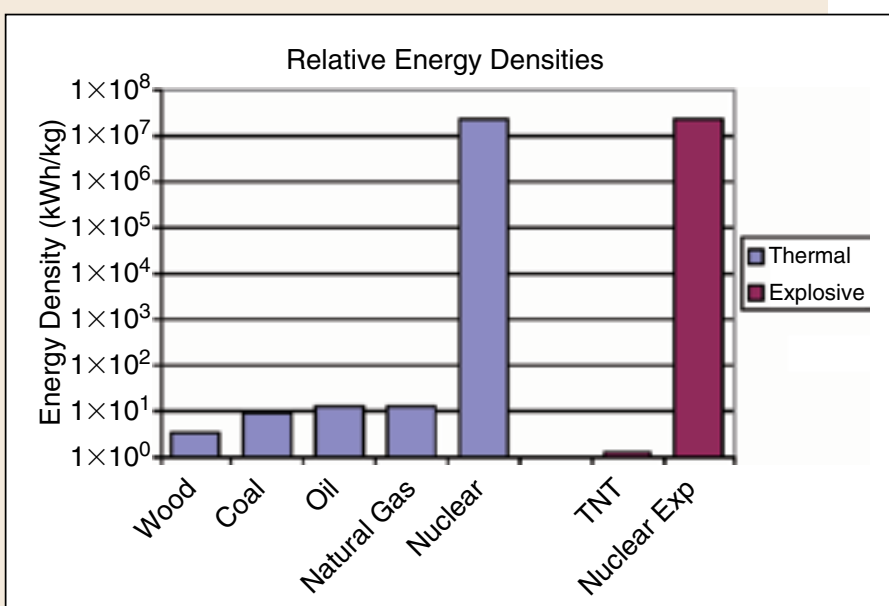

Figure 1. Relative energy densities for nuclear fission compared to conventional energy sources. 